Industrial Psychology and Take-over Bids

A study by Mrs. W. Raphael and Mr. M. W. Zimmerman of the reactions of some 5,500 employees in a group of electrical equipment companies indicates that unrest and anxiety among employees whose firm has been taken over by another could be reduced if they were given more information as soon as possible after the change occurs (National Institute of Industrial Psychology. Report No. 15: After the Take Over-A Study of Reactions of Employees in a Group of Companies. Pp. iii + 35. London: National Institute of Industrial Psychology, 1963). Two survoys were made: one shortly after the take-over, and a similar survey about a year later. At the time of the first survey, people were anxious about their jobs and initially excited rather than despondent about the future, and willing to co-operate rather than tending to resist all change. The Institute comments that even if few changes are intended, it is bettor to explain the nature of those that are intended than to say there will bo few. Em. ployees will be reassured more by knowledge of the direction that affairs will take than by general expressions of benevolence. The results of the second survey are treated with more reserve, and a particular distinction is suggested between the purposes of take-overs. On the whole, views about the effects on companies and on products and customers remained favourable. Ignoranco of the procedure by which a take-over is conducted was widespread: a circular which explained this procedure and its reasons could help to allay the suspicions to which misunderstandings lead.

\section{British Aid to Developing Countries}

A Ferther pamphlot in the serios of independent factual surveys of British aid being issued by the Overseas Development Institute, Ltd., reviews the main features of aid to developing countries, comploting the picture given in the White Paper issued in September (British Aid-1: Survey and Comment. Pp. 63. London: Overseas Dovelopmont Institute, Itd., 1963. 3s. 6d.). Objectives, organization, financial assistance, technical assistance and, finally, education and training, are discussed in successive chapters, and in the last three chapters the factual survey is followed by critical comments. As regards objectives, attention is directed to the nood for more public explanation and discussion of the more specific aims of aid if policy is to be deliberate, consistent and publicly supported. On organization, ostablishment of a Ministry for Overseas Devolopment with a sonior Ministor at its hoad is suggested. This Ministry would take ovor from the external affairs departments the responsibility for policy-making and allocation of aid. An Agoncy or service departmont, it considers, should be established to handlo the tochnical aspocts of aid, but policy would remain in the hands of the present departments-the Agency acting as adviser-while a senior Minister should bo appointed to act as general overseer of aid and its spokesman. The pamphlot is critical of some aspects of technical assistance, particularly emphasizing the noed for an overseas career service and suggosting also a home-based technical advisory sorvice. Accordingly, it suggests that recruitment could bo improved by making contracts significantly longer, and more attractive, and by moro detormined efforts at making an overseas tour of duty an accepted part of a successful career. On education, it questions whether the 7 por cent of Govornment aid devoted to oducational assistance ropresents the right order of magnitude. It strongly urges the need for more educational rosearch, particularly in determining the priorities of need in tho developing countries and the relative efficiency, and actual costing, of various methods of educational assistance. Apart from its value as a concise factual summary, the pamphlet is to bo commended for its constructive criticism which, except porhaps in the matter of organization, is sound as well as informed.

\section{Conservation of Nature and Landscape}

Ar the second meeting of the Committee of Experts for the conservation of Nature and landscapo, held in Strasbourg during November 12-15, Mr. J. P. Harroy (Belgium) was olectod chairman, and Mr. W. B. Yapp (Britain) and Mr. Z. Bayer (Turkey) were elected vice-chairmon. The agenda includod: soil conservation and unwise use of land; proparation of a map of potential natural vegetation in Europoan countries; water conservation; pesticides; sea pollution; criteria to be adopted for the selection of biotopes to be preserved in Europe and list of these biotopes; plant and animal species threatened by extinction; a European label for protocted objects; protectod areas in Furopo; oducation and information; national legislation on Nature conservation. The Committee of Experts asked the Committee of Ministers to recommond that mombor States: (1) take care in pursuing their forestry policies and conifor-planting projects to respect the principles of soil and water conservation and to protect fish and game; (2) ensure the protection of unusual biotopes and the preservation of the character and harmony of the landscape whenever these are threatened by such projerts; (3) take preventive measures to conserve aquatic life by reserving a strip of land on either side of water-courses where the natural vegetation must be conserved; (4) hasten the ratification of amendments to the 1954 International Convention for the prevention of Pollution of the Sea by Oil, and the provision of facilities for the recoption of oil residues in ports. The Committee of Ministers was also asked to repeat its recommendation to Governments to hasten the ratification and full application of the 1950 International Convention for the protection of birds. The next session of the Committeo is scheduled for July 21, 1964.

\section{Systematics}

THE Institute for the Comparative Study of History, Philosophy and the Sciences was founded in 1946 to conduct research and other scientific work relating to the problem of human porfectability, or the factors that determine progress or retrogression in individuals and communities. Coombe Springs, the headquarters of the Institute, has been a laboratory for studying ideas and methods directed to progress. Some of the rosults of this experimental work havo been published, and the desire to bring this work before a wider audience has led to the decision to launch a journal, Systematics, which is intended to become the principal medium for the publications of research work conducted by the Institute itself (1, No. 1; June 1963. The Journal of the Institute for the Comparativo Study of History, Philosophy and the Sciences. Pp. 1-103. Kingston upon Thamos: Coombe Springs Press, 1963. Annual subscription: 42s. non-members; 30s. members. Separate issues: $11 s$. 6d. non-mombors; 8s. 6d. members). The title has been chosen as expressing the fundamental notion of integration without rejection, which has been the guiding principle in the work at Coombe Springs. For papers to bo accepted for publication in the journal they must bear on the systematic hy pothesis and show sufficiont originality in content or treatment to contribute significantly to the better under. standing of human development: they may deal with any branch of history, philosophy and scionco, including psychology. Two numbers of the new journal have now been published. That for June 1963 includes, bosides J. G. Bennett's paper on general systematics, A. M. Hodgson's short paper on the education of technologists, describing a projoct of the Integral Science Education Research Group. The Septembor 1963 issue includes a paper, "Systematics of a Manufacturing Process", based on a study by the late C. F. King, ehief engineer of Vauxhall Motors, Ltd., and one by J. G. Bennett, "Geophysics and Human History", discussing some now light on Plato's Atlantis and the Fxodus. 